\title{
СЕМАНТИКО-ГРАМАТИЧНЕ НАПОВНЕННЯ ПОВТОРІВ В ІДІОСТИЛІ ІВАНА БАГРЯНОГО (на матеріалі роману «Людина біжить над прірвою»)
}

Стаття присвячена аналізу синтаксичних повторів, їхньоі ролі в структурно-смисловій організаи ї художніх творів Івана Багряного, зокрема роману "Людина біжить над прірвою». У науковому дослідженні виокремлено основні засоби експресивного синтаксису, шьо sрунтуються на повторі тих чи тих мовних одиниць; визначено особливості граматичного вираження різних стилістичних фігур повтору, простежено їхнє стилістичне й смислове навантаження в художньому тексті. Різноманітні за структурою, граматичним та лексико-семантичним наповненням, повторювані конструкиї сприяють художньому моделюванню внутрішнього світу героїв роману, увиразнюють авторську оповідь та слугують потужним засобом емоційного впливу на читача.

Ключові слова: ідіостиль Івана Багряного, експресивний синтаксис, стилістичні фігури, повтори, контекст.

Oleksenko O., Gusenko K. The Semantic and Grammatical Filling of Repetitions in Ivan Bagryany's Idiostyle (on the Material of the Novel «A Person is Running over the Abyss"). The article concentrates on the analysis of syntactic repetitions, their role in the structural and semantic organization of Ivan Bagryany's literary works, in particular, the novel "A person is running over the abyss", published after the author's death. The problem of grammatical expression of repetitive constructions in the idiosyncrasy of the writer needs a thorough study. This fact determines the demand in a generalized analysis of grammatical means that are used in repetitive constructions.

The aim of this scientific exploration is to identify the dominant figures of stylistic syntax, based on the principle of repetition, the specifics of their functioning and grammatical content in the artistic context of the novel «A person running over the abyss». The intended purpose includes the following tasks: to identify the main means of expressive syntax based on the repetition of certain language units; to trace their stylistic and semantic load in the literary text; to find out the role of stylistic figures of repetition in the formation of individual-authorial linguistic map of the world.

Describing deeply psychological pictures from the life of a Ukrainian who balanced between the Soviet military tribunal and the German occupation, equally dangerous for him during the war, Ivan Bagryany uses the expressive properties of syntactic repetition: anadiplosis, anaphora, epiphora, simplock, polysyndeton, chiasm, 
antithesis, "ring» and tautology. Some of the stylistic figures (especially anadiplosis, anaphora and polysyndeton) appear in the text more regularly and, therefore, play a more important role in the structural and semantic organization of the literary context, while others are less common (among them are epiphora, simplok, chiasm), but they are all important because they form the specifics of the writer's idiosyncrasy.

The analyzed material shows that the repetitive constructions are various in the structure, grammatical and lexical-semantic content of the novel. They contribute to the artistic modeling of the inner world of the novel's characters, tell the author's story and serve as a powerful means of emotional impact on the reader.

Key words: Ivan Bagryany's idiosyncrasy, expressive syntax, stylistic figures, repetitions, context.

\section{Вступ}

Оригінальне використання засобів загальнонаціональної мови властиве чи не кожному письменникові й грунтується воно, як правило, на взаємозалежності мовного й когнітивного аспектів. Відтак виникає поняття індивідуального стилю автора, що виявляє особливості світовідчуття митця за допомогою специфічних мовних засобів чи своєрідного оперування ними в художньому контексті. Як правило, особливу увагу лінгвістів привертає мовотворчість тих митців слова, які жили й займалися творчою діяльністю в складний і неоднозначний для історії країни період. Таким було, зокрема, позначене численними суспільно-політичними конфліктами ХХ століття. Серед українських письменників цієї доби чи не найважливіше місце посідає непересічна постать Івана Багряного, яскрава індивідуально-мовна манера якого була предметом зацікавлення багатьох лінгвістів (В. Русанівський, Н. Сологуб, О. Чумак та інші).

Серед мовних особливостей прози письменника найбільше уваги приділено аналізу порівняльних конструкцій, засобів експресивного синтаксису, фразеологічних сполук тощо. Однак така стилістична фігура, як повтор, його роль у структурно-смисловій організації художніх творів Багряного, зокрема роману «Людина біжить над прірвою», ще не стали предметом окремого наукового дослідження. Відповідно, проблема граматичного вираження, семантичного наповнення повторюваних конструкцій та стилістичного ефекту від їхнього вживання в художньому мовленні митця потребує грунтовного вивчення. У розв'язанні цього питання й убачаємо актуальність пропонованої статті. 
Мета наукової розвідки полягає у виявленні домінантних фігур стилістичного синтаксису, заснованих на принципі повтору, специфіки їхнього функціювання та граматичного наповнення в художньому контексті роману «Людина біжить над прірвою».

Реалізація мети наукового дослідження можлива за умови розв'язання таких завдань: 1) виокремити основні засоби експресивного синтаксису, що грунтуються на повторі тих чи тих мовних одиниць; 2) визначити засоби граматичного вираження різних стилістичних фігур повтору; 3) простежити їхнє стилістичне й смислове навантаження в художньому тексті; 4) з'ясувати роль стилістичних фігур повтору у формуванні індивідуально-авторської мовної картини світу; 5) довести, що повтор - одна з магістральних ознак художньої мовотворчості Івана Багряного (на матеріалі роману «Людина біжить над прірвою»).

Теоретичною базою для нашої наукової розвідки слугувала, зокрема, класифікація стилістичних фігур повтору, запропонована I. Дегтярьовою в роботі «Стилістичний потенціал української постмодерністської прози» (2009), та низка інших мовознавчих праць, де порушені питання експресивного синтаксису.

\section{Методи дослідження}

У процесі написання роботи були застосовані такі наукові методи: евристичниц̆, науково-пошуковий (для визначення типів повторюваних конструкцій, наявних у романі); описовий (для аналізу граматичного наповнення стилістичних фігур, заснованих на повторі); частково психологічний (для визначення емоційно-експресивного аспекту аналізованих одиниць та мотиваційного чинника вибору їх автором), інтерпретаиійно-текстовий аналіз (для виявлення змістової характеристики вживаних мовних одиниць як інструментів реалізації авторського задуму).

\section{Виклад основного матеріалу}

Повтор - це фігура мови, що полягає у дво- або кількаразовому використанні в межах контексту в певній послідовності тотожних чи подібних (у формальному та семантичному аспектах) звуків, слів або їхніх частин, синтаксичних конструкцій, ужитих компактно або дистантно, з метою досягнення відповідного виражального або 
виражально-зображального ефекту (Українська енциклопедія, 2004: 496). У сучасній лінгвістиці повтор - це явище багатоаспектне, поліфункційне; засіб посилення емоційно-експресивного, динамічного характеру оповіді, розвитку думки й, відповідно, семантичного простору тексту. Особливості цієї стилістичної фігури, специфіку ії граматичного вираження свого часу вивчали О. Шахматов, А. Загнітко, В. Ващенко, К. Шульжук, М. Плющ, В. Олексенко та ін.

Варто наголосити, що ми зупинимося саме на синтаксичних повторах, що трапляються в мові роману «Людина біжить над прірвою», не виділяючи при цьому в окрему групу лексичні повтори, оскільки, на переконання більшості лінгвістів, морфологічні, лексичні одиниці так чи так $є$ невід'ємними компонентами синтаксичних конструкцій. Попри все розмаїття класифікацій синтаксичних повторів, за основу наукового дослідження обрано ту, що ії запропонувала мовознавиця І. Дегтярьова: 1) повтор як різновид мовної гри; 2) антитетичний повтор; 3) синтаксичний анафоричний повтор; 4) епанафора; 5) полісиндетон; 6) повтор як засіб стилізації; 7) хіазм; 8) тавтологія (Дегтярьова, 2009). Окрім того, уважаємо за потрібне додати ще кілька типів синтаксичного повтору, що послідовно простежуються в мові роману «Людина біжить над прірвою»: епіфора; симплока (синтез анафори та епіфори); поліптотон (повторення слів у різних граматичних формах у межах речення або фрази); кільцевий повтор (повний або модифікований повтор важливих слів, речень, строф на початку й у кінці висловлення) тощо.

Зображуючи глибоко психологічні картини із життя українця, що в часи воєнного лихоліття балансує між радянським військовим трибуналом і німецькою окупацією, однаково небезпечними для нього, Іван Багряний сповна використовує експресивно-виражальні властивості повтору, досягаючи найбільшого емоційного ефекту, зокрема завдяки анадиплосису («підхоплення»).

В аналізованому романі цю фігуру найчастіше спостерігаємо в межах складнопідрядного речення для уточнення, доповнення вже сказаного новою інформацією, що, як правило, створює ефект драматичної напруженості, надає висловлюванню трагічного характеру. У ролі повторюваного елемента тут може виступати будь-який член речення (від головного до другорядного) i, як правило, будь-яка частина мови: A тоді вийняв пляшку з шкіряної торби, яку тримав 
під пахвою, відкоркував іï й простяг тому непритомному - простяг до самих уст (Багряний, 1992: 5) (тут - повторення однорідних ПДП); Він дивився в вікно, дослухаючись до тупоту, й думав... Думав про те, щз 25 років тому изію самою вулицею теж проходили юрби (Багряний, 1992: 17). Тут, окрім анадиплосису, фіксуємо парцеляцію - розчленування цілісної змістової структури на інтонаційно й пунктуаційно ізольовані комунікативні частини - окремі речення (просте речення з однорідними присудками (дивився і думав) завдяки анадиплосису трансформується у два окремих речення - основне (Він дивився в вікно, дослухаючись до тупоту, й думав...) і “парцелятивне” речення (складнопідрядне з'ясувальне: Думав про те, щзо 25 років тому иією самою вулицею теж проходили юрби). Або ж: Лише все повторював пошепки, що на нього кричали. Страшно кричали (Багряний, 1992: 101) - повторювані дієслова динамізують дію, створюють ефект свідомого нагнітання негативних думок; Він говорив із гіркотою й клекотом у горлі - клекотом гніву й сарказму... (Багряний, 1992: 102) - повторюваний іменник увиразнює трагічний характер повідомлюваного, створює ефект сильного емоційного напруження; I вже, здавалося, ніщо не могло зрушити той холод ні на одну риску вгору, лише вниз. Униз... (Багряний, 1992: 109) - повторюваний прислівник має семантику фатальної невідворотності подій, трагічної приреченості становища персонажів.

Ще одним типом синтаксичного повтору, що формує ідейноестетичну канву аналізованого твору, а отже, - і мовну особистість письменника, $є$ анафора, репрезентована здебільшого займенниками, частками, дієсловами, іменниками, прислівниками в різних за будовою та метою висловлювання реченнях.

Щодо дейктичних анафор, то в романі «Людина біжить над прірвою» найбільш поширені повтори особових (а саме - I-ї та II-ї особи множини (МИ, ВИ), III-ї особи однини й множини), питальних і заперечних займенників. У Багряного прономінативи входять переважно до предикативного центру - виступають у ролі підмета двоскладного простого речення або предикативної частини, співвідносної з таким реченням: Ніхто не мав вогню й ніхто не мав махорки. I ніхто не мав голосу, як ніхто вже тут не мав і свого власного обличчя. Нixто й не ворушився... (Багряний, 1992: 169). Поєднання заперечного займенника із заперечною часткою при дієслові несе в собі потужний 
семантичний заряд напруженого психічного стану персонажів, доведених до крайнього відчаю лихоліттям війни, що знецінює людську особистість.

Значно рідше в тексті роману трапляються анафоричні повтори неозначених займенників. До прикладу: Всі попадали з півкроку просто на землю, в калюжу. Хтось застогнав. Хтось зашепотів молитву. Хтось тиснувся з усієї сили тицем у воду, ніби хотів упірнуть, втікаючи від смерті... (Багряний, 1992: 183). Пряме значення займенника “невизначена особа" модифікується: повторюване “хтось” то не окремі люди, то ціла колона знеособлених арештантів, яких перед загрозою смерті охоплює масова психоза, що поступово розгортається в божевільне ревище; зникає дихотомія “усі - хтось окремий”.

Трапляються в романі й анафоричні конструкції з особовими займенниками: I от тепер - на нас поросте «чортополох»... Але він поросте й на вас... Але між тим «чортополохом» буде різниия. На нас поросте він, бо його посіють Джугашвілі й Вишінські. На них же той «чортополох» поросте сам. Його посіють вітри історіі. Та над нами потім, після «чортополоху», виросте щзось інше і той «чортополох» виглушить. А над ними нічого, крім «чортополоху», ніколи, ніколи, ніколи вже не виросте (Багряний, 1992: 107). Породжується антитеза "МИ - ВОНИ”, де "ми” (“на нас") - це національно свідомі українці, а “вони” (“на них”) - узагальнена вказівка на радянську владу. Із вказівними: Треба ж було тому рябому, тому невідомому салдатові, тому героєві пройти з боями шлях аж із-під Сталінграду, треба було пронести голову через усі бурі й вогні й треба було зберегти таке серце, щоб ось тут, отак по-дурному скласти це все до ніг... (Багряний, 1992: 159). Атрибутивним прономінативом той автор наголошує, що таких, як цей непоказний солдат, у країні мільйони, а повторюваним модальним прислівником треба й дієсловом-зв'язкою було підкреслює марність тих зусиль, що їх людина доклала, пройшовши пекло війни.

До складу анафоричних конструкцій у тексті роману «Людина біжить над прірвою» входять і такі частини мови, як прислівник: $\mathbf{H a в i -}$ щцо?.. Навіщо ж иі зайві страждання?.. Для неї.. для нього... для всіх... Навіщо?! (Багряний, 1992: 82) - анафора + кільцева конструкція породжує семантику абсурдності буття; частка: Він умре.. Але тільки переступивщи поріг свого дому. Тільки зазирнувщи в очі синкові 
й своїй вірній дружині, тільки посміхнувшись до них востаннє (Багряний, 1992: 189) - частка тільки виконує тут ідейно- й змістоутворювальну функцію, вона ніби визначає, окреслює й обмежує вектор думок та вчинків Колота: для нього головне - триматися курсу додому; іменник: Занадто великий жах охопив їх, щоб вони пам'ятали ще про когось, крім самих себе. Жах від усього. Жах від чужих $і$ жах від своїх. Жах від червоних і жах від брунатних. Жах від героїв і жах від звичайних злодіїв, душогубів. І... жах від «добрих людей» (Багряний, 1992: 248); прикметник: I це була остання людина, остання жінка, остання мати, щзо вийшла їх проводжати (Багряний, 1992: 149); дієслово: Боліла голова. Боліли ноги. Й боліли очі - від темряви, в яку він так вперто вдивлявся, й від вогню всередині, що, здавалося, вже випікав йому очі (Багряний, 1992: 239) тощо. Усі вони слугують, з одного боку, для конкретизації думки автора, а з другого, - для відтворення емоційної напруги персонажів твору.

Значно рідше трапляється синтаксична епіфора, репрезентована переважно прислівником та дієсловом: Іти страшно, тишатись страшно, вмерти страшно, жити теж страшно (Багряний, 1992: 190-191) - настрій тотальної безвиході посилюється ще й за допомогою антитетичних лексем “іти - лишатись”, “вмерти - жити”; Закривавленими ногами, але йти!.. У гарячиі, а таки йти! Наперекір усвому світові, такому злому й такому ворожому, йти! (Багряний, 1992: 216).

$€$ в тексті роману й така синтетична стилістична фігура, як симплока (анепіфора), заснована на поєднанні анафори та епіфори: Вони хотіли перепити себе - i не могли. Вони хотіли переспівати себе і не могли (Багряний, 1992: 7). Анафора “вони хотіли перепити / переспівати” та епіфора “i не могли” становлять предикативний центр простих двоскладних речень, ускладнених однорідними присудками, вираженими дієсловами із семантикою модальності, між якими створюються антитетичні відношення: вони хотіли... і не могли.

Досить поширеною в аналізованому романі $є$ й така фігура стилістичного синтаксису, як полісиндетон. У Багряного цей тип повтору різнорідний за своєю морфологічною природою (сполучники, частки, прийменники). Зокрема, письменник часто використовує багатосполучниковість як засіб експлікації (розкриття суті, сенсу повідомлюваного) почуттів, настроїв і вчинків героїв роману: Рід його, Максимів, дебелий і живучий, та все то прості люди, що не мали в більшості 
навіть початкової освіти, а душа ж потребує собі рівних, щзоб у часи критичні черпати собі силу з їхньої сили, щзоб кріпити себе снагою душі іншої (Багряний, 1992: 7). Тут спостерігаємо поєднання полісиндетона з ампліфікацією, що експресивізує висловлення, надає йому виразності шляхом розширення синтаксичної структури.

Полісиндетон у романі «Людина біжить над прірвою» слугує здебільшого засобом нагнітання негативних смислів, зокрема: I було Максимові соромно й гидко, $\boldsymbol{i}$ було йому тужно (Багряний, 1992: 7) - повторювана підсилювальна частка $i$ стоїть при інверсованому дієслові-зв'язці було - така синтаксична конструкція стилізована під народнопоетичне мовлення, а тому надає оповіді урочисто-трагічного характеру; Це було тоді, коли він щзодня ходив до школи й зі школи повз ие диво мистецтва, повз ию фортецю людської віри, повз ие прибіжище душ людських - $і$ його, Максимової, теж (Багряний, 1992: 32). Репрезентативна функція полісиндетона, заснованого на повторенні прийменника повз, реалізується в описі собору, що для Максима Колота став символом віри в духовність людини.

Фіксуємо в тексті роману й такі фрагменти, де полісиндетон поєднується з ампліфікацією та синтаксичним паралелізмом. Такий синтез стилістичних фігур сприяє, по-перше, експлікації почуттів героїв, створенню більш чіткої картини подій, по-друге, об'єднанню і водночас виокремленню кожного із синтаксичних компонентів як особливо значущого в ідейному та емоційно-експресивному аспектах, наприклад: Янгол плаче, затиснувши руки між коліна, а біля нього гуляють i будуть, може, ще гуляти байдужі люди, а над ним шумлять сосни, a на соснах иілуються горлиці... (Багряний, 1992: 30). Полісиндетон, виражений повторюваним сурядним (протиставним) сполучником $a$, поєднується з паралелізмом у межах складносурядного багатокомпонентного речення, набуваючи семантики трагічного протиставлення двох людських світів - свідомого й байдужого.

Почасти в романі «Людина біжить над прірвою» трапляється така стилістична риторична фігура, як хіазм. Хоч вона й не $є$ домінантною в мовотворчості Багряного, але також заслуговує на увагу. У романі хіазм спостерігаємо в межах одного чи двох окремих речень, наприклад: ...Доктор білософії й професор діямату глушив горілку чи горілкою глушив власну душу... (Багряний, 1992: 6). Важливо, що в наведеному реченні фіксуємо й такий прийом, як гра слів, 
обігрування смислів (глушити - жадібно пити щось; глушити - позбавляти здатності чути що-небудь).

Інший приклад хіазму: Я думаю, щзо хробакам Бог не потрібен, професоре!.. (Павза). Хробаки Богові - теж не потрібні, професоре!.. (Багряний, 1992: 18). Тут перехрещування спостерігаємо в межах двох речень і полягає в зміні позицій суб’єкта та адресата дії. I в першому, і в другому випадках хіазм виступає засобом вираження трагічної іронії.

Подекуди трапляється в романі ще одна стилістична фігура, заснована на повторі, - тавтологія. Ірунтується вона, як правило, на вживанні в межах одного речення дієслова й похідного від нього іменника (...Ненавиділи тих $і$ тих страшною зненавистю (Багряний, 1992: 41); У дружини сльози не втрималися в очах і потекли буйним потоком (Багряний, 1992: 54); ...А Максимове серие все ще тремтіло дрібним тремтінням (Багряний, 1992: 163), повторенні ідентичних за формою, але різних за семантикою прикметників (Це він десь там плаче - мармуровий янгол у мармуровій печалі... (Багряний, 1992: 30) або спільнокореневих іменників із різними суфіксами переважно демінутивними (Та цее ж син! Це ж його синок!. Синочок!! (Багряний, 1992: 170)) тощо. У наведених фрагментах тавтологія здебільшого поєднується з висхідною градацією, створюючи настрої безвиході, розпачу, страху, трагічної іронії тощо.

$€$ в аналізованому творі незначна кількість поліптотонів (повторення одного й того самого слова в різних граматичних формах). У Багряного він грунтується переважно на повторенні дієслів у різних часових формах (Той, що його Максим, як справжній єретик, уперто не визнавав, не визнає й визнавати не хоче й не буде» (Багряний, 1992: 63); ...Легіон виконавців, щзо з іменем того свого «генія» на прапорах доконували й доконують нечувані злочини... (Багряний, 1992: 107)) та прикметників у формі нульового й вищого або найвищого ступенів порівняння (Дитяче містечко», що потім стало військовим (військ НКВД) «городком» зі страшною репутацією, а щзе пізніше - резидениією Гестапо з іще страшнішою репутацією (Багряний, 1992: 60)). Як бачимо, поліптотон поєднується з висхідною градацією, так набуваючи семантики постійної дії, що тривала й триватиме за будь-яких умов (у разі повторенням часових дієслівних форм), або ж семантики посиленого вияву ознаки (повторення ад'єктивних граматичних форм). 


\section{Висновки}

Отже, з вищезазначеного можемо зробити певні висновки. Повтор - це одна з тих стилістичних фігур, що домінують у тексті роману «Людина біжить над прірвою» і, відповідно, визначають своєрідність мовотворчості Івана Багряного. Серед усього розмаїття засобів експресивного синтаксису, заснованих на повторі, в аналізованому творі переважають такі: анадиплосис, анафора, епіфора, симплока, полісиндетон, хіазм, антитеза, кільце й тавтологія.

Окремі стилістичні фігури (серед них - анадиплосис, анафора та полісиндетон) виявляються в тексті більш регулярно й, відтак, відіграють вагомішу роль у структурно-семантичній організації художнього контексту, інші ж - менш поширені (серед них - епіфора, симплока, хіазм), однак вони також важливі, оскільки формують специфіку ідіостилю письменника. Різноманітні за структурою, граматичним та лексико-семантичним наповненням, повторювані конструкції сприяють художньому моделюванню внутрішнього світу героїв роману, увиразнюють авторську оповідь та слугують потужним засобом емоційного впливу на читача.

Багатство мовно-виражальних засобів ідіостилю Івана Багряного невичерпне й потребує все нових лінгвістичних розвідок. Перспективним уважаємо дослідження стилістично скерованих повторів службових частин мови, зокрема такої фігури, як полісиндетон, оскільки ці, на перший погляд, непримітні слова мають значний художньо-семантичний потенціал.

\section{ЛIТЕРАТУРА}

1. Акимова, Г. Н. (1990). Новое в синтаксисе современного русского языка: учеб. пособ. Москва: Высш. шк. 2. Багряний, I. (1992). Людина біжить над прірвою. Київ: Укр. письм. 3. Ващенко, В. С. (1958). Стилістичні явища в українській мові. Харків: Держвидав. 4. Вихованець, І. Р., \& Городенська, К. Г. (2004). Теоретична морфологія української мови. Київ: Пульсари. 5. Дегтярьова, I. О. (2009). Стилістичний потенціал української постмодерністської прози. (Дис. ... канд. філол. наук). Київ: Ін-т укр. мови НАН України. 6. Загнітко, А. П. (2001). Теоретична граматика української мови: Синтаксис. Донецьк: ДонНУ. 7. Русанівський, В. М. (2001). Історія украӥнської літературної мови. Київ: АртЕк. 8. Сологуб, Н. М. (1993). Біблійні образи в художній творчості Івана Багряного. Київ: Наук. думка. 9. Чумак, О. Г. (2001). Художньо-семіотична парадигма у мовотворчості І. Багряного. Наук. вісн. кафедри ЮНЕСКО Київ. держ. лінгвіст. ун-ту, 4, 221-226.

\section{REFERENCES}

1. Akimova, G. N. (1990). Novoe v sintaksise sovremennogo russkogo yazyka [New in the syntax of the modern Russian language]. Moskva: Vyssh. shk. [in Russian]. 2. Bahrianyi, I. (1992). Liudyna bizhyt nad prirvoiu [A person running over the abyss]. Kyiv: Ukr. pysm. [in Ukrainian]. 3. Vashchenko, V. S. (1958). Stylistychni yavyshcha v ukrainskii movi 
[Stylistic phenomena in the Ukrainian language]. Kharkiv: Derzhvydav [in Ukrainian]. 4. Vykhovanets, I. R., \& Horodenska, K. G. (2004). Teoretychna morfolohiia ukrayinskoyi movy [Theoretical morphology of the Ukrainian language]. Kyiv: Pulsary [in Ukrainian]. 5. Dehtiarova, I. O. (2009). Stylistychnyi potentsial ukrainskoi postmodernistskoi prozy [Stylistic Potential of Ukrainian Postmodernist Prose]. Candidate's thesis. Kyiv: In-t ukr. movy NAN Ukrainy [in Ukrainian]. 6. Zahnitko, A. P. (2001). Teoretychna hramatyka ukrainskoi movy: Syntaksys [Theoretical grammar of the Ukrainian language: Syntax]. Donetsk: DonNU [in Ukrainian]. 7. Rusanivskyi, V. M. (2001). Istoriia ukrainskoi literaturnoi movy [History of the Ukrainian literary language]. Kyiv: ArtEk [in Ukrainian]. 8. Solohub, N. M. (1993). Bibliini obrazy v khudozhnii tvorchosti Ivana Bahrianoho [Biblical visions in the literary legacy of Ivan Bagryany]. Kyiv: Nauk. dumka [in Ukrainian]. 9. Chumak, O. H. (2001). Khudozhno-semiotychna paradyhma u movotvorchosti I. Bahrianoho [Artistic and semiotic paradigm in I. Bagryany's language style]. Nauk. visn. kafedry YuNESKO Kyiv. derzh. linhvist. un-tu [Scientific Bulletin of the UNESCO Department of Kyiv State Linguistic University], 4, 221-226 [in Ukrainian]. 10. Ukrainska mova: Entsyklopediia [The Ukrainian language: Encyclopedia]. (2004). Kyiv: Ukr. entsykl. [in Ukrainian].

Олексенко Олена Андріївна - кандидат філологічних наук, професор, професор кафедри української мови, Харківський національний педагогічний університет імені Г. С. Сковороди; вул. Валентинівська, 2, Харків, 61168, Україна.

Tel.: +380972896846

E-mail: oleksenkoolena@gmail.com

http://orcid.org/0000-0002-6541-8040

Oleksenko Olena Andriivna - Candidate of Philological Sciences (Ph.D.), Professor, Professor at the Department of Ukrainian Language, H. S. Skovoroda Kharkiv National Pedagogical University; 2 Valentynivska Str., Kharkiv, 61168, Ukraine.

Гусенко Крістіна Вікторівна - студентка українського мовно-літературного факультету імені Г. Ф. Квітки-Основ’яненка, Харківський національний педагогічний університет імені Г. С. Сковороди; вул. Валентинівська, 2, м. Харків, 61168, Україна.

Tel.: +38-097-294-09-89

E-mail: gusenko.kristina2000@gmail.com

Husenko Kristina Viktorivna - Student at the Faculty of Ukrainian Language and Literature named after Hryhorii Kvitka-Osnovianenko, H. S. Skovoroda Kharkiv National Pedagogical University; 2 Valentynivska Str., Kharkiv, 61168, Ukraine.

\section{CITATION}

Надійшла до редакції 13 березня 2021 року

ДСТУ 8302:2015: Олексенко О. А., Гусенко К. В. Семантико-граматичне наповнення повторів в ідіостилі Івана Багряного (на матеріалі роману «Людина біжить над прірвою»). Лінгвістичні дослідження: зб. наук. пр. Харк. нац. пед. ун-ту імені Г. С. Сковороди. Харків, 2021. Вип. 54. Ч. І. С. 165-175. DOI: https://doi.org/10.34142/ 23127546.2021.54.1.14

APA: Олексенко, О. А., \& Гусенко, К. В. (2021). Семантико-граматичне наповнення повторів в ідіостилі Івана Багряного (на матеріалі роману «Людина біжить над прірвою»). Лінгвістичні дослідження, 54 (I), 165-175. DOI: https://doi.org/10.34142/ 23127546.2021.54.1.14 